\title{
Transgenerational Induction of Resistance to Phytophthora cinnamomi in Holm Oak
}

\author{
María Vivas ${ }^{1} \mathbb{D}$, Jerónimo Hernández ${ }^{1}$, Tamara Corcobado ${ }^{2}$, Elena Cubera ${ }^{1}$ and Alejandro Solla ${ }^{1, *(D)}$ \\ 1 Faculty of Forestry, Institute for Dehesa Research (INDEHESA), University of Extremadura, Avenida Virgen \\ del Puerto 2, 10600 Plasencia, Spain; vivas@unex.es (M.V.); jerobosqueurbano@gmail.com (J.H.); \\ ecubera@unex.es (E.C.) \\ 2 Phytophthora Research Centre, Mendel University in Brno, Zemědělská 3, 61300 Brno, Czech Republic; \\ tamara.corcobado@mendelu.cz \\ * Correspondence: asolla@unex.es; Tel.: +34-927-257000 (ext. 52189)
}

check for updates

Citation: Vivas, M.; Hernández, J.; Corcobado, T.; Cubera, E.; Solla, A. Transgenerational Induction of Resistance to Phytophthora cinnamomi in Holm Oak. Forests 2021, 12, 100. https://doi.org/10.3390/f12010100

Received: 3 December 2020

Accepted: 15 January 2021

Published: 18 January 2021

Publisher's Note: MDPI stays neutral with regard to jurisdictional claims in published maps and institutional affiliations.

Copyright: (c) 2021 by the authors. Licensee MDPI, Basel, Switzerland. This article is an open access article distributed under the terms and conditions of the Creative Commons Attribution (CC BY) license (https:/ / creativecommons.org/licenses/by/ $4.0 /)$.
Abstract: The maternal environment of a tree species can influence the development and resistance of its offspring. Transgenerational induction of resistance is well known in plants but its occurrence in forest tree species has been less reported. Quercus ilex L. (holm oak) is a widespread Mediterranean tree species threatened by the invasive Phytophthora cinnamomi Rands pathogen. The influence of $P$. cinnamomi on the offspring of infected $Q$. ilex mother trees has not been studied. This study compared the performance and tolerance to $P$. cinnamomi of seedlings from non-infected and $P$. cinnamomiinfected trees. Acorns from $Q$. ilex trees were collected from five forests. After isolations were conducted in the rhizosphere of several trees, in each forest, three trees were selected as non-infected and three were selected as P. cinnamomi-infected. Forty acorns per tree were weighed and sown under greenhouse conditions, and when plants were aged $\sim 9$ months they were challenged with $P$. cinnamomi. Plant mortality was higher in the offspring of non-infected trees than in the offspring of P. cinnamomi-infected trees ( $26.2 \%$ vs. $21.1 \%$, respectively). Consistently, survival probabilities of seedlings from $P$. cinnamomi-infected trees were higher than those of seedlings from non-infected trees, particularly in seedlings with reduced growth. Although acorns from healthy $Q$. ilex trees were heavier than acorns from P. cinnamomi-infected trees, the time to death of inoculated seedlings was not influenced by seed weight. The time to death of seedlings was positively related to belowground mass, particularly to an increased proportion of fine secondary roots. We report transgenerationalinduced resistance to P. cinnamomi in $Q$. ilex triggered by an unknown mechanism independent of acorn mass. Information about the persistence of transgenerational effects in $Q$. ilex offspring and the influence of these effects on plant fitness is crucial to improve the management and regeneration of this declining species.

Keywords: forest decline; holm oak; maternal effects; phenotypic plasticity; seed mass

\section{Introduction}

The biotic and abiotic conditions in which a plant species develops can influence its offspring phenotype and resistance across generations [1-3]. This transgenerational plasticity, also known as maternal effects, is independent of DNA changes $[1,3,4]$. The effects of the parental environment on plant offspring are transmitted by seed provisioning and epigenetic modifications [3,5]. Seed provisioning is a non-heritable mechanism in which mother plants provide seeds with valuable resources for their development $[3,6]$. Epigenetic modifications are heritable mechanisms capable of modifying gene expression through DNA methylation, histone modifications and small RNAs [7-9]. Repeated exposure of trees to stress may cause transcriptional memory in a process known as 'priming' $[10,11]$. Although transgenerational effects of plant stress are the subject of increasing research, evidence for transgenerational passage of acquired resistance to biotic stress in trees is scarce $[11,12]$. 
Transgenerational plasticity can play a role in rapid adaptations of plant species to climate change [13]. In contrast to DNA changes, transgenerational plasticity is induced by the parental environment in a short timescale [14]. The parental environment can preadapt seedlings to different stressors when both generations are exposed to the same environmental conditions $[15,16]$, e.g., seed traits and seedling performance are influenced by parental environmental conditions in many plant species [14,17-19]. Moreover, herbivory on maternal plants produces seedlings more resistant to herbivory compared to control plants $[9,20,21]$, indicating a transgenerational defence induction. Transgenerational plasticity could therefore give an advantage to seedlings that experience the same stress conditions as their parents in the current context of forest decline.

The decline of forests is a worldwide phenomenon that is expected to increase due to climate change [22,23]. Holm oak (Quercus ilex L.) forests are suffering a severe process of decline in Portugal, Italy and Spain that is leading to tree mortality [24-27]. In the southwest of the Iberian Peninsula, $Q$. ilex is part of open savanna-type woodlands known as dehesas, which cover more than 3 million ha and are an agroforestry system of paramount importance [28]. The most common symptoms of $Q$. ilex decline are leaf discolouration and wilting, crown transparency, root rot and branch dieback followed by tree death [29-31].

The oomycete Phytophthora cinnamomi Rands is considered the main biotic driver of holm oak decline $[24,25,30,32]$ and is one of the most threatening invasive pathogens in the world $[33,34]$. This microorganism is responsible for fine-root infections followed by root girdling and tree death $[32,35]$. Other factors involved in $Q$. ilex mortality include soil texture, land use, prolonged drought, waterlogging, lack of mycorrhization and other Phytophthora species [36-39], most of which interact with P. cinnamomi severity [27,40]. Despite substantial recent progress in characterising $Q$. ilex decline (e.g., [41-44]) and $Q$. ilex regeneration $[45,46]$, the transgenerational effects of $P$. cinnamomi infection in offspring are unknown.

The influence on offspring of mother tree infection by P. cinnamomi has been studied only in Castanea sativa [19]. It was reported that ink-diseased chestnut trees produced smaller seedlings with increased tolerance to P. cinnamomi in comparison to non-diseased trees [19]. In this study, we hypothesised that $Q$. ilex decline induced by P. cinnamomi influences performance and susceptibility to $P$. cinnamomi in offspring. The first objective of this study was to compare, in a greenhouse experiment, the morphological traits of seedlings obtained from non-infected healthy mother trees with seedlings obtained from $P$. cinnamomi-infected mother trees. The second objective was to assess tolerance to $P$. cinnamomi in offspring of non-infected and P. cinnamomi-infected mother trees.

\section{Materials and Methods}

\subsection{Plant Material}

In November 2010, acorns from Q. ilex ssp. ballota trees were collected from 5 dehesa forests in Cáceres, western Spain. These forests were characterised by a scattered tree layer of $Q$. ilex trees aged $\sim 70$ to 100 years and an understory of grazed pasture dominated by annual native species. More than $50 \%$ of trees at each of the 5 study forests were declining, and P. cinnamomi was the primary biotic cause of decline $[24,37,40]$. The 5 forests (Abadía, Cuartón, Haza, San Esteban and Vegaviana) have a dry Mediterranean climate, with an average annual rainfall of $\sim 680 \mathrm{~mm}$, mainly from December to May. The mean minimum and maximum temperatures are in January $\left(7.4^{\circ} \mathrm{C}\right)$ and August $\left(28.7^{\circ} \mathrm{C}\right)$, respectively. Vegaviana was the least favourable forest for $Q$. ilex growth, because it had the lowest soil water content in the summer $(<15 \% \mathrm{vol}$ in the first $\mathrm{m}$ of soil depth) and the highest water table fluctuations [37]. At the time of acorn collection, Cuartón showed higher disease prevalence and tree mortality due to P. cinnamomi than the other four forests (see [40] for more details about the forests).

In each forest, $6 Q$. ilex trees were selected, and 3 were classified as noninfected (healthy) and 3 as P. cinnamomi-infected (unhealthy). Isolations of P. cinnamomi from fine roots of the unhealthy trees confirmed infection, while no P. cinnamomi was isolated from 
fine roots of healthy trees. The occurrence of P. cinnamomi was assessed in May 2010 by taking 25 fine roots per tree from 4 points around the tree. Sampling was performed 1-2 m from the trunks at depths of 10-40 cm. Immediately after collection, roots $\sim 5-6 \mathrm{~cm}$ long were cut into $1 \mathrm{~cm}$ segments (discarding the outermost segments), surface sterilised ( $2 \mathrm{~min}$ in $1 \%$ aqueous sodium hypochlorite), rinsed with sterile water, blotted dry and plated on Petri dishes containing NARPH selective medium [40]. Nine plates per tree containing $\sim 10$ fine root segments each were incubated $24 \mathrm{~h}$ in the dark at $24{ }^{\circ} \mathrm{C}$. After $2-3$ days, the selected isolates were transferred to a carrot agar medium. Colonies were identified by microscopic observations of distinctive structures, including clustered hyphal swellings, chlamydospores and sporangia.

Seventy acorns per tree were collected and stored at $4{ }^{\circ} \mathrm{C}$ for 2 weeks. The acorns collected belonged to the rotundifolia morphotype. Forty acorns per tree were randomly selected and individually measured and weighed. In total, 1200 acorns were used, corresponding to 5 forests $\times 2$ health statuses of mother trees $\times 3$ trees $\times 40$ acorns per tree. In December 2010, acorns were sown in plastic root trainers, with 1 acorn per cell. Acorns were arranged following a random design replicated in 40 blocks. Each block contained 1 root trainer, and acorns were randomly positioned within each block. In all blocks, each mother tree (30 in total) was represented by 1 seedling. Individual cells were approximately $300 \mathrm{~mL}$ in volume and $18 \mathrm{~cm}$ high and contained a mixture of sand and peat (1:1, pH 6.3). In each cell, a polythene tube of $2 \mathrm{~cm}$ in diameter and $10 \mathrm{~cm}$ long was inserted behind the acorn to create a hollow for subsequent inoculation of plants with P. cinnamomi inoculum. Plants were kept in natural daylight under greenhouse shade that reduced solar radiation by $50 \%$ and watered to field capacity every 4 days until they were established. The greenhouse is at the Faculty of Forestry in Plasencia, University of Extremadura, Spain $\left(40^{\circ} 02^{\prime} \mathrm{N}, 6^{\circ} 04^{\prime} \mathrm{W} ; 374 \mathrm{~m}\right.$ a.s.1.).

\subsection{Inoculation and Assessment of Plants}

Inoculum was prepared following the procedure of Jung et al. [47] by mixing and twice autoclaving $500 \mathrm{~cm}^{3}$ of fine vermiculite, $40 \mathrm{~cm}^{3}$ of whole oat grains and $350 \mathrm{~mL}$ of multivitamin juice broth $\left(200 \mathrm{~mL} \mathrm{~L}^{-1}\right.$ Campbell's V8 juice, $800 \mathrm{~mL} \mathrm{~L}^{-1}$ deionised water amended with $\left.3 \mathrm{~g} \mathrm{~L}^{-1} \mathrm{CaCO}_{3}\right)$ in $1 \mathrm{~L}$ Erlenmeyer flasks. The flasks were inoculated with agar discs from actively growing V8-agar cultures of $P$. cinnamomi A2 (code UEx1) and incubated at $23{ }^{\circ} \mathrm{C}$ in the dark for 6 weeks. The colonised medium was rinsed with demineralised water to remove excess nutrients before soil infestation. In September 2011, after discarding plants affected or killed during summer by thermal and drought stress, 342 seedlings obtained from non-infected $Q$. ilex mother trees and 364 seedlings obtained from P. cinnamomi-infected $Q$. ilex mother trees were inoculated. Then, $20 \mathrm{~mL}$ of inoculum per cell was placed inside the hollow created after removal of the polythene tube and covered with the upper substrate. After inoculation, plant containers were allowed to drain normally but were flooded the following day. Every 5 weeks until the end of the experiment, plants were waterlogged for $48 \mathrm{~h}$ to stimulate production of Phytophthora sporangia and release and spread of zoospores.

After seeding, acorn germination was assessed weekly for 4 months. Acorn germination was considered successful when the epicotyl emerging from the embryo was green. Before inoculation, plant height and stem diameter at the root collar were measured. After inoculation, plant mortality was assessed weekly for 28 weeks, until April 2012. Dead seedlings were destructively sampled to obtain parameters of plant performance (plant height and dry weight of stem, main root and secondary fine roots). Seedlings that survived infection were destructively sampled in April 2012, when fine roots of 1 seedling per root trainer were used for Phytophthora re-isolations. Necrotic and non-necrotic fine roots were abundantly washed with tap water, cut into 6-8 mm segments (15 segments per seedling), dried on filter paper and separately plated on PARPH-V8 selective medium [48]. Plates were incubated for $2-4$ days at $23^{\circ} \mathrm{C}$ in the dark. The isolates obtained by re-isolations 
from the inoculated plants matched the morphology of the P. cinnamomi species used and confirmed that the soil infestations had resulted in successful infections.

\subsection{Data Analysis}

To explore differences in weight, shape (i.e., length, diameter, length-to-diameter ratio), germination rat, and time to germinate between acorns from mother trees infected with or free of P. cinnamomi, linear mixed models (LMM) were used. 'Health status of mother tree' (infected or non-infected), 'forest' (Abadía, Cuartón, Haza, San Esteban and Vegaviana) and their interaction were included as explanatory variables in the model. In addition, 'mother tree' was nested within 'health status of mother tree' and 'forest' and was considered as a random variable. The same LMM were run to explore differences in plant height, stem diameter, dry weight of stems, roots and fine roots, root-to-stem dry weight ratio and fine root-to-root dry weight ratio between offspring from mother trees infected with or free of P. cinnamomi.

Seedling resistance to P. cinnamomi was assessed by comparing the 'time to death' (survival time after inoculation) in offspring of non-infected vs. P. cinnamomi-infected mother trees, using an LMM as described above. The analysis included data from dead seedlings only. Because seed weight and size differed between the health status of the mother tree and the forest (Table 1), the model was run both including and excluding the individual seed mass as a covariate in the model to properly quantify the extent to which the maternal effects observed were mediated by seed provisioning [18,49].

Table 1. Results of the linear mixed models used to analyse traits of acorns and seedlings obtained from non-infected and Phytophthora cinnamomi-infected Quercus ilex L. mother trees. F values and significance levels $\left({ }^{*}, p<0.05 ;{ }^{* *}, p<0.01 ;{ }^{* * *}, p<0.001\right)$ for each fixed factor are shown.

\begin{tabular}{|c|c|c|c|}
\hline \multirow[t]{2}{*}{ Trait } & \multicolumn{3}{|c|}{ Fixed Factors } \\
\hline & Health Status of Mother Tree (H) & Forest (F) & $\mathbf{H} \times \mathbf{F}$ \\
\hline Acorn weight (g) & $23.6^{* * *}$ & $171.1^{* * *}$ & $127.9^{* * *}$ \\
\hline Acorn length (mm) & $27.7^{* * *}$ & $47.5^{* * *}$ & $43.5^{* * *}$ \\
\hline Acorn diameter (mm) & 0.4 & $160.1^{* * *}$ & $87.6^{* * *}$ \\
\hline Acorn length-to-diameter ratio & $31.6^{* * *}$ & $13.4^{* * *}$ & $39.7^{* * *}$ \\
\hline Time to germinate (days) & 1.9 & $3.7 * *$ & 1.3 \\
\hline Plant height $(\mathrm{cm})$ & 1.0 & 0.8 & 1.7 \\
\hline Stem diameter $(\mathrm{mm})$ & 1.2 & 2.1 & $4.8^{* * *}$ \\
\hline Stem dry weight (mg) & 0.8 & $8.0^{* * *}$ & $11.5^{* * *}$ \\
\hline Root dry weight (mg) & 1.6 & $5.7^{* * *}$ & $3.9^{* * *}$ \\
\hline Fine root dry weight (mg) & 3.5 & $5.9^{* * *}$ & 1.0 \\
\hline Root-to-stem dry weight ratio & $5.0 *$ & $2.5 *$ & 1.0 \\
\hline Fine root-to-root dry weight ratio & $10.5 * *$ & $3.8^{* *}$ & 1.8 \\
\hline
\end{tabular}

A second approach to assess the 'time to death' of plants was through survival analysis [50]. Survival probabilities were determined using the Kaplan-Meier estimate, and seedlings that were alive at the end of the experiment were considered as censored (i.e., unknown time to death). To test for statistical differences between survival probabilities of progenies from different 'health status of mother tree,' the log-rank test was used. Survival analysis does not account for the effect of continuous covariates on survival probabilities. To assess whether 'plant height' influenced offspring susceptibility to $P$. cinnamomi (as observed by Camisón et al. [19] for Castanea sativa), the log-rank test was run, both including and excluding 'plant height' as a split factor of the plant material. When taking 'plant height' into account, the plant material was classified into 4 groups: offspring $1-10 \mathrm{~cm}$ tall from non-infected mother trees $(n=222$ seedlings), offspring $1-10 \mathrm{~cm}$ tall from P. cinnamomi-infected mother trees $(n=261)$, offspring $>10 \mathrm{~cm}$ tall from non-infected mother trees $(n=120)$ and offspring $>10 \mathrm{~cm}$ tall from $P$. cinnamomi-infected mother trees $(n=103)$ [19]. To assess whether 'forest' influenced offspring survival probabilities to $P$. 
cinnamomi, the survival of seedlings from non-infected and P. cinnamomi-infected mother trees was analysed in each forest.

Normality and homoscedasticity of all variables were checked by Kolmogorov-Smirnoff and Bartlett's tests. Tukey HSD tests $(\alpha=0.05)$ were used to test differences between average values. Relations between the early performance of seedlings and the time-to-death parameters were examined using Pearson correlation coefficients in seedlings from non-infected and P. cinnamomi-infected mother trees. All analyses were performed with STATISTICA v.10 software.

\section{Results}

Acorns from healthy $Q$. ilex trees were significantly heavier and longer than acorns from P. cinnamomi-infected trees (Tables 1 and 2). Acorn length-to-diameter ratio was significantly influenced by the tree health status, given that acorns obtained from noninfected $Q$. ilex trees were slightly longer than acorns from P. cinnamomi-infected trees (Tables 1 and 2). All morphological traits assessed in acorns were significantly influenced by the forest (Table 1). Tree infection by P. cinnamomi did not influence germination rates or time to germinate of acorns (Table 2).

Table 2. Traits (mean values $\pm \mathrm{SE}$ ) of acorns and seedlings obtained from non-infected and Phytophthora cinnamomi-infected Quercus ilex L. mother trees. n.s. indicates non-significant $p$ values. Significant $p$-values are indicated in bold.

\begin{tabular}{cccc}
\hline Trait & $\begin{array}{c}\text { From Non-Infected } \\
\text { Mother Tree }\end{array}$ & $\begin{array}{c}\text { From Infected } \\
\text { Mother Tree }\end{array}$ & $p$-value \\
\hline Acorn weight (g) & $4.39 \pm 0.06$ & $4.18 \pm 0.06$ & $<\mathbf{0 . 0 0 1}$ \\
Acorn length (mm) & $33.8 \pm 0.1$ & $32.87 \pm 0.2$ & $<\mathbf{0 . 0 0 1}$ \\
Acorn diameter (mm) & $14.4 \pm 0.1$ & $14.4 \pm 0.1$ & $\mathrm{~ns}$ \\
Acorn length-to-diameter ratio & $2.37 \pm 0.01$ & $2.29 \pm 0.01$ & $<\mathbf{0 . 0 0 1}$ \\
Germination (\%) & 73.6 & 70.0 & - \\
Time to germinate (days) & $99 \pm 2$ & $92 \pm 2$ & $\mathrm{~ns}$ \\
Plant height (cm) & $9.2 \pm 0.2$ & $8.8 \pm 0.1$ & $\mathrm{~ns}$ \\
Stem diameter (mm) & $2.3 \pm 0.1$ & $2.3 \pm 0.1$ & $\mathrm{~ns}$ \\
Stem dry weight (mg) & $0.33 \pm 0.01$ & $1.46 \pm 0.04$ & $\mathrm{~ns}$ \\
Root dry weight (mg) & $1.41 \pm 0.04$ & $0.50 \pm 0.02$ & $\mathrm{~ns}$ \\
Fine root dry weight (mg) & $0.51 \pm 0.01$ & $4.93 \pm 0.11$ & $\mathbf{0 . 0 2 5}$ \\
Root-to-stem dry weight ratio & $4.49 \pm 0.10$ & $0.32 \pm 0.00$ & $\mathbf{0 . 0 0 1}$ \\
Fine root-to-root dry weight ratio & $0.34 \pm 0.01$ & & \\
\hline
\end{tabular}

Seedling height and weight were not influenced by the health status of mother trees (Tables 1 and 2). However, root-to-stem ratio was highest in plants from P. cinnamomiinfected trees, and fine root-to-root dry weight was highest in seedlings from healthy trees (Tables 1 and 2). Mortality was higher in seedlings of healthy trees than in seedlings of $P$. cinnamomi-infected trees ( $26.2 \%$ vs. $21.1 \%$, respectively).

Without taking seed weight covariance into account, the health status of the mother tree significantly affected the time to death of seedlings (LMM in Table 3, left). The effect of the health status of mother tree on the time to death of seedlings was not affected when individual seed mass was taken as a covariate in the LMM (Table 3, right). On average, the time to death of seedlings from healthy and P. cinnamomi-infected trees was $9.2 \pm 0.7$ days and $11.6 \pm 0.6$ days, respectively. The time to death of seedlings was not influenced by 'forest' or by the 'health status of the mother' $\times$ 'forest' interaction (Table 3 ). 
Table 3. Results of the linear mixed model for analysis of time to death of Quercus ilex L. seedlings inoculated with Phytophthora cinnamomi. Seedlings were obtained from healthy and P. cinnamomi-infected Q. ilex trees. Analyses including and excluding acorn weight as a covariate are shown. Degrees of freedom (DF) and F-ratios of fixed factors, and variance components (VarComp) and associated $\chi^{2}$ of random factors are shown. Significant $p$-values are indicated in bold.

\begin{tabular}{|c|c|c|c|c|c|c|}
\hline \multirow{2}{*}{ Effects } & \multicolumn{3}{|c|}{$\begin{array}{c}\text { Not Accounting for } \\
\text { acorn weight Covariance }\end{array}$} & \multicolumn{3}{|c|}{$\begin{array}{c}\text { Accounting for } \\
\text { acorn weight Covariance }\end{array}$} \\
\hline & DF/VarComp & $F$-ratio/ $\chi^{2}$ & $p$-value & DF/VarComp & $F$-ratio/ $\chi^{2}$ & $p$-value \\
\hline \multicolumn{7}{|l|}{ Fixed factors } \\
\hline Health status of mother tree $(\mathrm{H})$ & 1 & 5.0 & 0.032 & 1 & 5.1 & 0.031 \\
\hline Forest $(\mathrm{F})$ & 4 & 0.1 & 0.984 & 4 & 0.1 & 0.985 \\
\hline $\mathrm{H} \times \mathrm{F}$ & 4 & 2.7 & 0.057 & 4 & 2.6 & 0.055 \\
\hline Acorn weight & & & & 1 & 0.1 & 0.776 \\
\hline \multicolumn{7}{|l|}{ Random factor } \\
\hline Mother tree $(\mathrm{H} \times \mathrm{F})^{1}$ & $53.2 \pm 35.0$ & 1.5 & 0.086 & $51.0 \pm 34.8$ & 1.4 & 0.104 \\
\hline
\end{tabular}

The survival analysis confirmed the results obtained through the LMM. Survival probabilities were higher in seedlings from P. cinnamomi-infected trees than seedlings from healthy trees (Figure 1a). The group of plants $1-10 \mathrm{~cm}$ tall from $P$. cinnamomi-infected trees showed lower mortality at a slower rate than the other groups of plants (Figure 1b). Survival probabilities of seedlings from healthy trees were significantly different among forests (Figure 2a). However, if mother trees were infected by P. cinnamomi, differences in survival probabilities were not significant (Figure $2 b$ ).

(a)

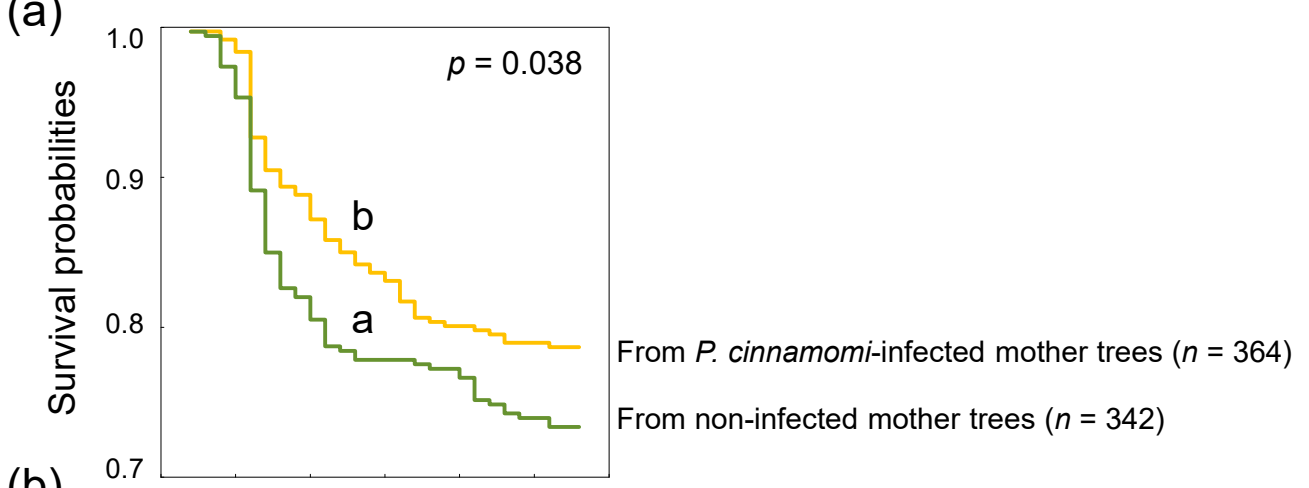

(b)

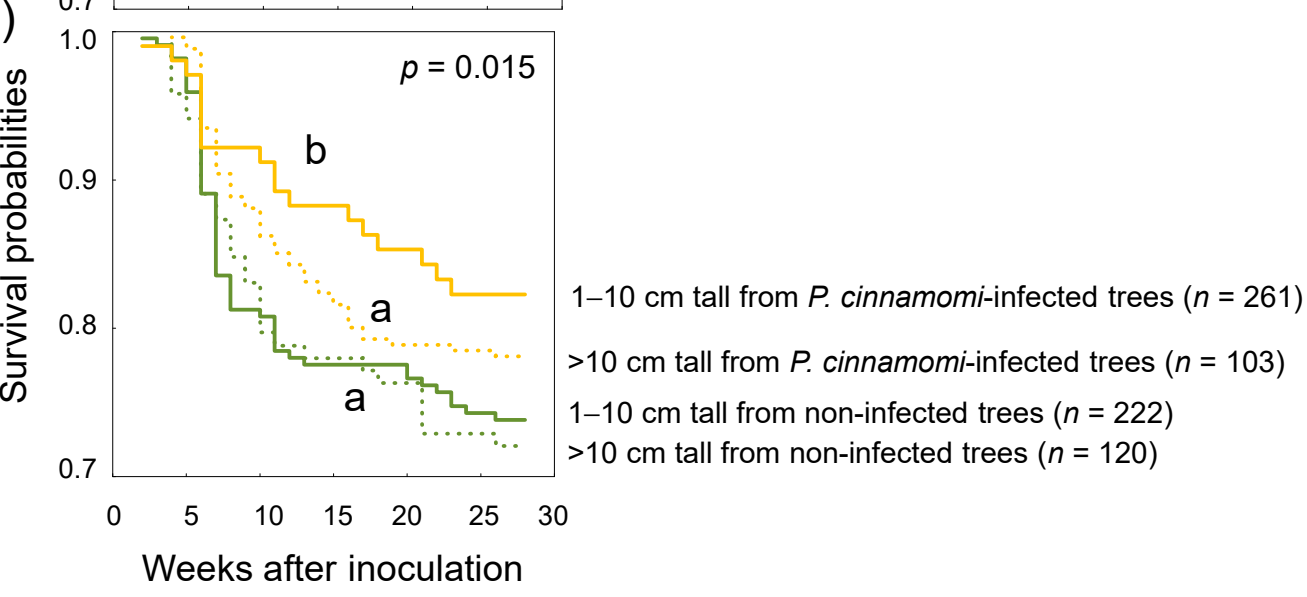

Figure 1. Survival probabilities of Quercus ilex seedlings inoculated with Phytophthora cinnamomi at week 0. (a) Seedlings were derived from non-infected and P. cinnamomi-infected mother trees. (b) Seedlings were classified into four groups: 1-10 $\mathrm{cm}$ tall from non-infected mother trees, 1-10 cm tall from $P$. cinnamomi-infected mother trees, $>10 \mathrm{~cm}$ tall from non-infected mother trees and $>10 \mathrm{~cm}$ tall from $P$. cinnamomi-infected mother trees. $P$-values are provided from the global log-rank tests, with different letters indicating significant differences between survival curves $(p<0.05)$. 
(a)

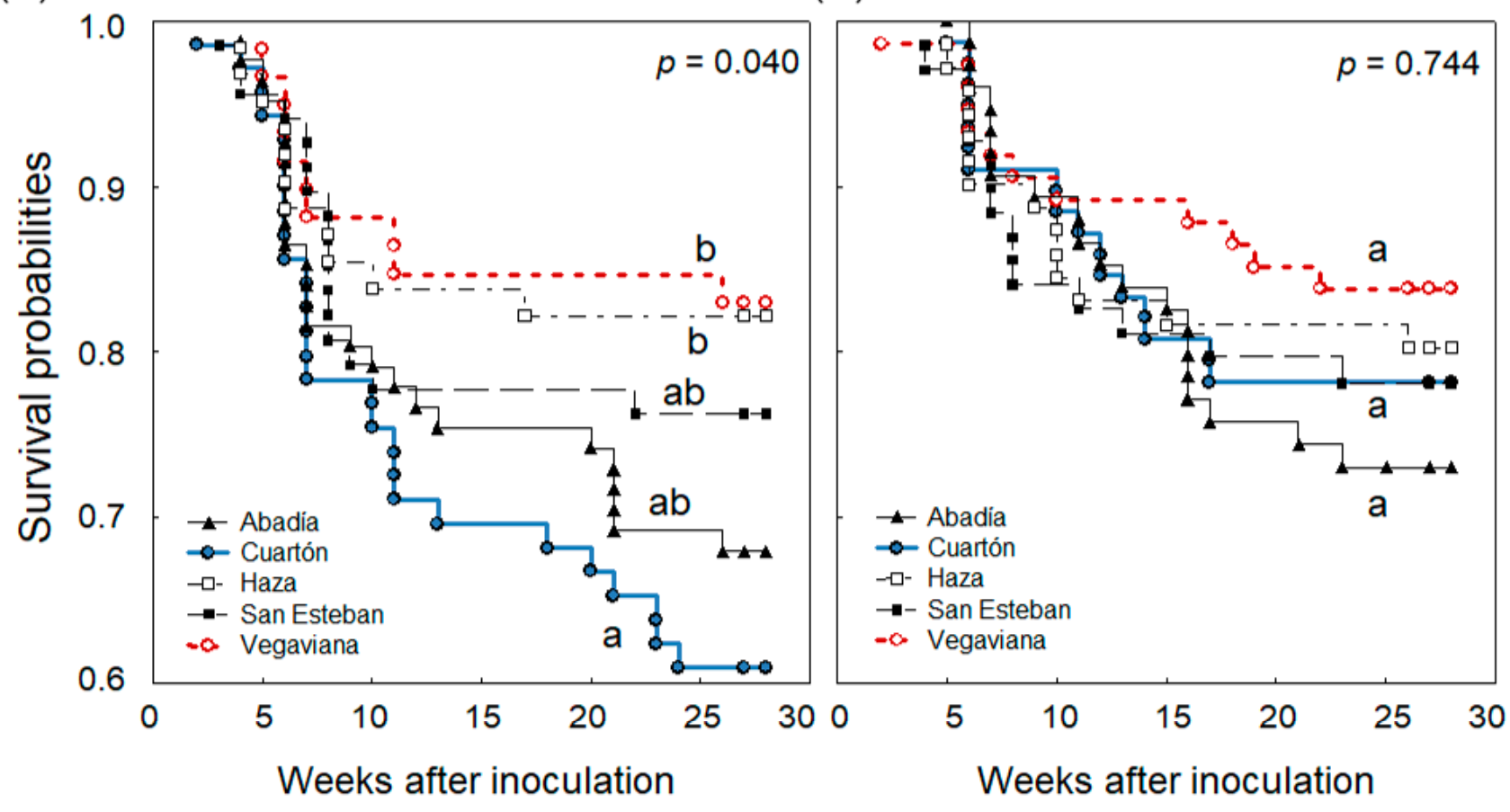

Figure 2. Survival probabilities of Quercus ilex seedlings inoculated with Phytophthora cinnamomi at week 0. Seedlings were derived from (a) non-infected and (b) P. cinnamomi-infected mother trees, collected in five forests (Abadía, Cuartón, Haza, San Esteban, Vegaviana). $P$-values are provided from the global log-rank tests, with different letters indicating significant differences between survival curves $(p<0.05)$.

Pearson correlation analysis showed similar relations between variables in seedlings of healthy and P. cinnamomi-infected trees (Table 4). Seedlings with early germination were smaller in size and died significantly later than seedlings with late germination (Table 4). 'Root weight' and 'fine root weight' were positively related to 'time to death.' 'Root-to-stem' and 'fine root-to-root' dry weight ratios were also predictive of 'time to death' (Table 4). 


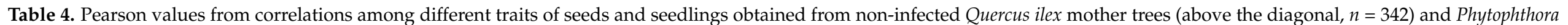
cinnamomi-infected $Q$. ilex mother trees (below the diagonal, $n=364$ ). Asterisks indicate levels of significance at ${ }^{*} p<0.05,{ }^{* *} p<0.01$ and ${ }^{* * *} p<0.001 ; n s=$ non-significant $p$-values.

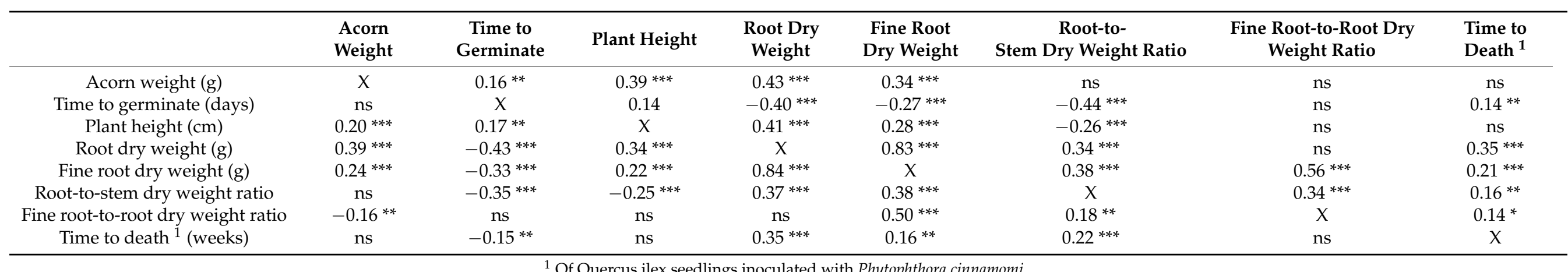

${ }^{1}$ Of Quercus ilex seedlings inoculated with Phytophthora cinnamomi. 


\section{Discussion}

Transgenerational effects in plants are the subject of increasing research [51-54]. However, to our knowledge, the influence of the health status of a forest tree on offspring behaviour to a pathogen has been reported only for Pinus pinaster, Eucalyptus grandis and C. sativa $[19,49,55-58]$. This is the first study to explore the transgenerational effects of $P$. cinnamomi infection on offspring of $Q$. ilex. The results show that the health status of $Q$. ilex mother trees influences acorn weight, acorn size and subsequent seedling performance. It was also observed that $Q$. ilex trees infected with $P$. cinnamomi produced seedlings that were more resistant to the pathogen than healthy trees. This occurred even after considering the differential seed provisioning in the model, suggesting that transgenerational defensive plasticity to P. cinnamomi in Q. ilex offspring was not related solely to biomass allocation of seeds.

Seed weight is an important life-history trait that has strong effects on offspring phenotype and fitness [59]. The quantity and composition of resources allocated to seeds are strongly influenced by the environment [60], and this may result in large differences in mean seed weight among conspecific trees from different forests [61], as observed here. In Quercus spp., positive relations have been reported between seed size and time to germinate [62-64] and between seed size and subsequent seedling size [63,65-67]. Our results, showing a large difference in seedling growth depending on the environment where the seeds developed (Table 1), could be explained by the influence of the resources allocated to seeds by mother trees. Acorns were heaviest and longest when collected from healthy Q. ilex trees (Table 2), in accordance with previous studies comparing traits of seeds collected from stressed and non-stressed trees $[18,19,49,68]$.

Based on acorn morphology and size, different morphotypes of $Q$. ilex subsp. ballota have been described [69]. When seedlings from acorns collected from healthy trees of four Q. ilex subsp. ballota morphotypes (microcarpa, macrocarpa, rotundifolia and expansa) were inoculated with P. cinnamomi, higher foliar symptoms were developed by microcarpa plants than by macrocarpa and rotundifolia plants [70]. Lower concentrations of condensed tannins were reported in acorns of macrocarpa and rotundifolia trees than in acorns of other $Q$. ilex morphotypes [71], although this is probably not linked to differences in susceptibility. According to our results, susceptibility of the two subspecies of $Q$. ilex (ballota and ilex) to $P$. cinnamomi was not related to acorn weight [64]. In C. sativa, however, life expectancy of seedlings challenged with P. cinnamomi covaried positively with seed weight and time to emerge [72]. These results are not comparable to ours, because half our plant material was collected from P. cinnamomi-infected trees. In our study, the time to death of inoculated seedlings was influenced by the health status of the mother tree, irrespective of whether acorn weight was included in the analysis (Table 3). Moreover, acorn weight and time to death of seedlings were not correlated in either of the two groups according to the health status of mother trees (Table 4). This implies that the transgenerational response of plant resistance is not mediated by seed provisioning $[49,55,56,58]$. Instead, an epigenetic mechanism could transmit increased resistance to the progeny. Although the identification of epigenetic mechanisms is beyond the scope of this paper, our result suggests that adaptation of $Q$. ilex to $P$. cinnamomi between generations could be persistent, as in other plant species $[7,9]$. This finding, together with the variable response of $Q$. ilex populations to P. cinnamomi (Figure 2a), opens up opportunities for the natural recovery of $Q$. ilex in the long term.

The time to death of seedlings was positively related to belowground mass, particularly to an increased proportion of fine secondary roots (Table 4). Because P. cinnamomi destroys fine roots by degrading the host cell walls [73], higher availability of fine roots seems to be a useful trait for plants. This observation is in accordance with the relevance of fine roots as indicators of tree vitality in Phytophthora infested sites [37,74]. Moreover, seedlings from P. cinnamomi-infected trees showed higher root-to-stem and fine root-to-root dry weight ratios than seedlings from healthy trees. Our result hypothesises a possible transgenerational effect in which seedlings from infected mother trees invest more re- 
sources belowground than seedlings from healthy trees to counter the negative effects of root rot caused by the pathogen.

The survival probability of seedlings was influenced not only by the health status of the mother trees but also by plant height. Seedlings $1-10 \mathrm{~cm}$ tall from P. cinnamomiinfected trees showed significantly higher survival probabilities than seedlings from the other groups of plants (Figure 1b). This agrees with the results of Camisón et al. [19], which showed increased tolerance to P. cinnamomi in small-sized seedlings of C. sativa. As suggested by previous authors, increased tolerance to $P$. cinnamomi may involve costs in plant growth. This growth-defence trade-off observed in offspring of P. cinnamomiinfected mother trees is supported by ecological theories on plant defence, such as the 'resource availability hypothesis' and the 'growth development balance hypothesis' [75, 76]. Small oak plants could have been primed for resistance, probably by chromatin modifications, either DNA methylation or histone changes $[77,78]$, although this needs further investigation.

It is not known why seedlings from healthy trees had different survival probabilities depending on the forest (Figure 2a), whereas seedlings from P. cinnamomi-infected trees had similar survival probabilities irrespective of the forest (Figure $2 b$ ). The biotic stress induced by P. cinnamomi in mothers (irrespective of the forest) appears to have limited adaptive plasticity in response to P. cinnamomi in offspring. Analysis of differences in survivorship between seedlings of healthy and P. cinnamomi-infected trees showed that only the offspring of Abadía, Cuartón and San Esteban forests contributed to these differences (Figure 2). Vegaviana did not significantly contribute to differences in survivorship in offspring, probably because it was the least favourable forest for $Q$. ilex growth due to limited water availability in summer [37]. The Cuartón forest contributed most to differences in survivorship in offspring, probably because it was the site in which $P$. cinnamomi occurrence was highest [40]. More mother trees and more forests should be studied to confirm our results. The use of clonally replicated material would have enabled us to properly distinguish between heritable genetic variation and maternal environmental effects, but unfortunately there are no clonal stands of $Q$. ilex and vegetative propagation of this recalcitrant species is in an initial phase $[79,80]$. Further studies on transgenerational induced defence should consider plant size and use several isolates, including some with low virulence, to capture greater sensitivity in the offspring.

\section{Conclusions}

Induced resistance, a well-known phenomenon in forestry, may generate trees resistant to a specific stress if the parent tree has been exposed to the same cue. We reported transgenerational-induced resistance to P. cinnamomi in Q. ilex triggered by an unknown mechanism independent of acorn mass. Information about persistence of transgenerational effects in $Q$. ilex offspring and the influence of these effects on plant fitness is crucial to improve management and regeneration of this species.

Author Contributions: A.S. conceived and designed the research; E.C. coordinated the IV-PRI project; J.H. and T.C. conducted the experiments; M.V. and A.S. analysed the data and wrote the first draft of the manuscript; all authors contributed to the preparation of the final manuscript. All authors have read and agreed to the published version of the manuscript.

Funding: This research was funded by the Government of Extremadura and EU ERDF (Consejería de Economía, Comercio e Innovación, IV-PRI project) and the Spanish Ministry of Economy and Competitiveness (project AGL2011-30438 and IJCI-2017-34640 contract of MaríaVivas).

Acknowledgments: We thank Andrea Pérez and Delicias Espada for assistance in data collection, Thomas Jung for technical advice and Jane McGrath for English editing of the manuscript.

Conflicts of Interest: The authors declare no conflict of interest. 


\section{References}

1. Roach, D.A.; Wulff, R.D. Maternal effects in plants. Annu. Rev. Ecol. Syst. 1987, 18, 209-235. [CrossRef]

2. Donohue, K. Completing the cycle: Maternal effects as the missing link in plant life histories. Philos. Trans. R. Soc. Lond. Ser. B Biol. Sci. 2009, 364, 1059-1074. [CrossRef]

3. Herman, J.J.; Sultan, S.E. Adaptive transgenerational plasticity in plants: Case studies, mechanisms, and implications for natural populations. Front. Plant Sci. 2011, 2, 1-10. [CrossRef] [PubMed]

4. Rossiter, M.C. Incidence and consequences of inherited environmental effects. Annu. Rev. Ecol. Syst. 1996, 27, 451-476. [CrossRef]

5. Elwell, A.L.; Gronwall, D.S.; Miller, N.D.; Spalding, E.P.; Brooks, T.L.D. Separating parental environment from seed size effects on next generation growth and development in Arabidopsis. Plant Cell Environ. 2011, 34, 291-301. [CrossRef] [PubMed]

6. Metz, J.; Liancourt, P.; Kigel, J.; Harel, D.; Sternberg, M.; Tielbörger, K. Plant survival in relation to seed size along environmental gradients: A long-term study from semi-arid and Mediterranean annual plant communities. J. Ecol. 2010, 98, 697-704. [CrossRef]

7. Boyko, A.; Kovalchuk, I. Genome instability and epigenetic modification-Heritable responses to environmental stress? Curr. Opin. Plant Biol. 2011, 14, 260-266. [CrossRef]

8. Herman, J.J.; Sultan, S.E.; Horgan-Kobelski, T.; Riggs, C. Adaptive transgenerational plasticity in an annual plant: Grandparental and parental drought stress enhance performance of seedlings in dry soil. Integr. Comp. Biol. 2012, 52, 77-88. [CrossRef]

9. Holeski, L.M.; Jander, G.; Agrawal, A.A. Transgenerational defense induction and epigenetic inheritance in plants. Trends Ecol. Evol. 2012, 27, 618-626. [CrossRef]

10. Mauch-Mani, B.; Baccelli, I.; Luna, E.; Flors, V. Defense priming: An adaptive part of induced resistance. Ann. Rev. Plant Biol. 2017, 68, 485-512. [CrossRef]

11. Amaral, J.; Ribeyre, Z.; Vigneaud, J.; Sow, M.D.; Fichot, R.; Messier, C.; Pinto, G.; Nolet, P.; Maury, S. Advances and promises of epigenetics for forest trees. Forests 2020, 11, 976. [CrossRef]

12. Vivas, M.; Wingfield, M.J.; Slippers, B. Maternal effects should be considered in the establishment of forestry plantations. For. Ecol. Manag. 2020, 460, 117909. [CrossRef]

13. Skrøppa, T.; Tollefsrud, M.M.; Sperisen, C.; Johnsen, Ø. Rapid change in adaptive performance from one generation to the next in Picea abies-Central European trees in a Nordic environment. Tree Genet. Genom. 2010, 6, 93-99. [CrossRef]

14. Yakovlev, I.; Fossdal, C.G.; Skrøppa, T.; Olsen, J.E.; Jahren, A.H.; Johnsen, Ø. An adaptive epigenetic memory in conifers with important implications for seed production. Seed Sci. Res. 2012, 22, 63-76. [CrossRef]

15. Galloway, L.F.; Etterson, J.R. Transgenerational plasticity is adaptive in the wild. Science 2007, 318, 1134-1136. [CrossRef]

16. Baker, B.H.; Berg, L.J.; Sultan, S.E. Context-dependent developmental effects of parental shade versus sun are mediated by DNA methylation. Front. Plant Sci. 2018, 9, 1-15. [CrossRef]

17. Violle, C.H.; Castro, H.; Richarte, J.; Navas, M.L. Intraspecific seed trait variations and competition: Passive or adaptive response? Funct. Ecol. 2009, 23, 612-620. [CrossRef]

18. Cendán, C.; Sampedro, L.; Zas, R. The maternal environment determines the timing of germination in Pinus pinaster. Environ. Exp. Bot. 2013, 94, 66-72. [CrossRef]

19. Camisón, Á.; Martín, M.Á.; Oliva, J.; Elfstrand, M.; Solla, A. Increased tolerance to Phytophthora cinnamomi in offspring of ink-diseased chestnut (Castanea sativa Miller) trees. Ann. For. Sci. 2019, 76. [CrossRef]

20. Agrawal, A.A. Herbivory and maternal effects: Mechanisms and consequences of transgenerational induced plant resistance. Ecology 2002, 83, 3408-3415. [CrossRef]

21. Rasmann, S.; Vos, M.D.; Casteel, C.L.; Tian, D.; Halitschke, R.; Sun, J.Y.; Agrawal, A.A.; Felton, G.W.; Jander, G. Herbivory in the previous generation primes plants for enhanced insect resistance. Plant Physiol. 2012, 158, 854-863. [CrossRef] [PubMed]

22. Allen, C.D.; Macalady, A.K.; Chenchouni, H.; Bachelet, D.; McDowell, N.; Vennetier, M.; Kitzberger, T.; Rigling, A.; Breshears, D.D.; Hogg, E.H.; et al. A global overview of drought and heat-induced tree mortality reveals emerging climate change risks for forests. For. Ecol. Manag. 2010, 259, 660-684. [CrossRef]

23. Anderegg, W.R.L.; Kane, J.M.; Anderegg, L.D.L. Consequences of widespread tree mortality triggered by drought and temperature stress. Nat. Climate Change 2013, 3, 30-36. [CrossRef]

24. Corcobado, T.; Solla, A.; Madeira, M.A.; Moreno, G. Combined effects of soil properties and Phytophthora cinnamomi infections on Quercus ilex decline. Plant Soil 2013, 373, 403-413. [CrossRef]

25. Frisullo, S.; Lima, G.; Lio, G.M.d.S.; Camele, I.; Melissano, L.; Puglisi, I.; Pane, A.; Agosteo, G.E.; Prudente, L.; Cacciola, S.O. Phytophthora cinnamomi involved in the decline of holm oak (Quercus ilex) stands in southern Italy. For. Sci. 2018, 64, $290-298$. [CrossRef]

26. Hernández-Lambraño, R.E.; González-Moreno, P.; Sánchez-Agudo, J.Á. Environmental factors associated with the spatial distribution of invasive plant pathogens in the Iberian Peninsula: The case of Phytophthora cinnamomi Rands. For. Ecol. Manag. 2018, 419, 101-109. [CrossRef]

27. Gea-Izquierdo, G.; Natalini, F.; Cardillo, E. Holm oak death is accelerated but not sudden and expresses drought legacies. Sci. Total Environ. 2021, 754, 141793. [CrossRef]

28. Sánchez-Martín, J.-M.; Blas-Morato, R.; Rengifo-Gallego, J.-I. The Dehesas of Extremadura, Spain: A potential for socio-economic development based on agritourism activities. Forests 2019, 10, 620. [CrossRef]

29. Gallego, F.J.; Algaba, A.P.D.; Fernandez-Escobar, R. Etiology of oak decline in Spain. Eur. J. For. Pathol. 1999, 29, 17-27. [CrossRef] 
30. Camilo-Alves, C.d.S.e P.; da Clara, M.I.E.; Ribeiro, N.M.C.d.A. Decline of Mediterranean oak trees and its association with Phytophthora cinnamomi: A review. Eur. J. For. Res. 2013, 132, 411-432. [CrossRef]

31. Solla, A.; García, L.; Pérez, A.; Cordero, A.; Cubera, E.; Moreno, G. Evaluating potassium phosphonate injections for the control of Quercus ilex decline in SW Spain: Implications of low soil contamination by Phytophthora cinnamomi and low soil water content on the effectiveness of treatments. Phytoparasitica 2009, 37, 303-316. [CrossRef]

32. Brasier, C.M.; Robredo, F.; Ferraz, J. Evidence for Phytophthora cinnamomi involvement in Iberian oak decline. Plant Pathol. 1993, 42, 140-145. [CrossRef]

33. Burgess, T.I.; Scott, J.K.; Mcdougall, K.L.; Stukely, M.J.C.; Crane, C.; Dunstan, W.A.; Brigg, F.; Andjic, V.; White, D.; Rudman, T.; et al. Current and projected global distribution of Phytophthora cinnamomi, one of the world's worst plant pathogens. Glob. Change Biol. 2017, 23, 1661-1674. [CrossRef]

34. Sena, K.; Crocker, E.; Vincelli, P.; Barton, C. Phytophthora cinnamomi as a driver of forest change: Implications for conservation and management. For. Ecol. Manag. 2018, 409, 799-807. [CrossRef]

35. Martín-García, J.; Solla, A.; Corcobado, T.; Siasou, E.; Woodward, S. Influence of temperature on germination of Quercus ilex in Phytophthora cinnamomi, P. gonapodyides, P. quercina and P. psychrophila infested soils. For. Pathol. 2015, 45, 215-223. [CrossRef]

36. Corcobado, T.; Vivas, M.; Moreno, G.; Solla, A. Ectomycorrhizal symbiosis in declining and non-declining Quercus ilex trees infected with or free of Phytophthora cinnamomi. For. Ecol. Manag. 2014, 324, 72-80. [CrossRef]

37. Corcobado, T.; Cubera, E.; Moreno, G.; Solla, A. Quercus ilex forests are influenced by annual variations in water table, soil water deficit and fine root loss caused by Phytophthora cinnamomi. Agric. For. Meteorol. 2013, 169, 92-99. [CrossRef]

38. Gómez, F.J.R.; Pérez-de-Luque, A.; Sánchez-Cuesta, R.; Quero, J.L.; Cerrillo, R.M.N. Differences in the response to acute drought and Phytophthora cinnamomi rands infection in Quercus ilex L. seedlings. Forests 2018, 9, 634. [CrossRef]

39. Mora-Sala, B.; Gramaje, D.; Abad-Campos, P.; Berbegal, M. Diversity of Phytophthora species associated with Quercus ilex L. in three Spanish regions evaluated by NGS. Forests 2019, 10, 979. [CrossRef]

40. Corcobado, T.; Moreno, G.; Azul, A.M.; Solla, A. Seasonal variations of ectomycorrhizal communities in declining Quercus ilex forests: Interactions with topography, tree health status and Phytophthora cinnamomi infections. Forestry 2015, 88, 257-266. [CrossRef]

41. Gallardo, A.; Morcuende, D.; Solla, A.; Moreno, G.; Pulido, F.; Quesada, A. Regulation by biotic stress of tannins biosynthesis in Quercus ilex: Crosstalk between defoliation and Phytophthora cinnamomi infection. Physiol. Plant. 2019, 165, 319-329. [CrossRef] [PubMed]

42. Ruiz-Gómez, F.J.; Pérez-de-Luque, A.; Navarro-Cerrillo, R.M. The involvement of Phytophthora root rot and drought stress in holm oak decline: From ecophysiology to microbiome Influence. Curr. For. Rep. 2019, 5, 251-266. [CrossRef]

43. García-Angulo, D.; Hereş, A.-M.; Fernández-López, M.; Flores, O.; Sanz, M.J.; Rey, A.; Valladares, F.; Curiel Yuste, J. Holm oak decline and mortality exacerbates drought effects on soil biogeochemical cycling and soil microbial communities across a climatic gradient. Soil Biol. Biochem. 2020, 149, 107921. [CrossRef]

44. Ruiz Gómez, F.J.; Navarro-Cerrillo, R.M.; Pérez-de-Luque, A.; Oßwald, W.; Vannini, A.; Morales-Rodríguez, C. Assessment of functional and structural changes of soil fungal and oomycete communities in holm oak declined dehesas through metabarcoding analysis. Sci. Rep. 2019, 9, 5315. [CrossRef]

45. Garcia-Fayos, P.; Nicolau, J.M.; Espigares, T.; Bochet, E.; Monleon, V.J. Increasing aridity threatens the sexual regeneration of Quercus ilex (holm oak) in Mediterranean ecosystems. PLoS ONE 2020, 15, e0239755. [CrossRef]

46. García de Jalón, L.; Limousin, J.-M.; Richard, F.; Gessler, A.; Peter, M.; Hättenschwiler, S.; Milcu, A. Microhabitat and ectomycorrhizal effects on the establishment, growth and survival of Quercus ilex L. seedlings under drought. PLoS ONE 2020, 15, e0229807. [CrossRef]

47. Jung, T.; Blaschke, H.; Neumann, P. Isolation, identification and pathogenicity of Phytophthora species from declining oak stands. Eur. J. For. Pathol. 1996, 26, 253-272. [CrossRef]

48. Ferguson, A.J.; Jeffers, S.N. Detecting multiple species of Phytophthora in container mixes from ornamental crop nurseries. Plant Dis. 1999, 83, 1129-1136. [CrossRef]

49. Vivas, M.; Zas, R.; Sampedro, L.; Solla, A. Environmental maternal effects mediate the resistance of maritime pine to biotic stress. PLOS ONE 2013, 8. [CrossRef]

50. Solla, A.; Aguín, O.; Cubera, E.; Sampedro, L.; Mansilla, J.P.; Zas, R. Survival time analysis of Pinus pinaster inoculated with Armillaria ostoyae: Genetic variation and relevance of seed and root traits. Eur. J. Plant Pathol. 2011, 130, 477-488. [CrossRef]

51. McIntyre, P.J.; Strauss, S.Y. Phenotypic and transgenerational plasticity promote local adaptation to sun and shade environments. Evol. Ecol. 2014, 28, 229-246. [CrossRef]

52. Dewan, S.; Frenne, P.D.; Broeck, A.V.; Steenackers, M.; Mijnsbrugge, K.V.; Verheyen, K. Transgenerational effects in asexually reproduced offspring of Populus. PLoS ONE 2018, 13, e0208591. [CrossRef] [PubMed]

53. Dong, B.-C.; Alpert, P.; Yu, F.-H. Transgenerational effects of herbivory and soil nutrients transmitted via vegetative reproduction in the clonal plant Alternanthera philoxeroides. Perspect. Plant Ecol. Evol. Syst. 2019, 100632. [CrossRef]

54. Yin, J.; Zhou, M.; Lin, Z.; Li, Q.Q.; Zhang, Y.-Y. Transgenerational effects benefit offspring across diverse environments: A meta-analysis in plants and animals. Ecol. Lett. 2019. [CrossRef]

55. Vivas, M.; Nunes, C.; Coimbra, M.A.; Solla, A. Maternal effects and carbohydrate changes of Pinus pinaster after inoculation with Fusarium circinatum. Trees 2014, 28, 373-379. [CrossRef] 
56. Vivas, M.; Nunes, C.; Coimbra, M.A.; Solla, A. Antioxidant activity of Pinus pinaster infected with Fusarium circinatum is influenced by maternal effects. For. Pathol. 2014, 44, 337-340. [CrossRef]

57. Vivas, M.; Rolo, V.; Wingfield, M.J.; Slippers, B. Maternal environment regulates morphological and physiological traits in Eucalyptus grandis. For. Ecol. Manag. 2019, 432, 631-636. [CrossRef]

58. Vivas, M.; Kemler, M.; Mphahlele, M.M.; Wingfield, M.J.; Slippers, B. Maternal effects on phenotype, resistance and the structuring of fungal communities in Eucalyptus grandis. Environ. Exp. Bot. 2017, 140, 120-127. [CrossRef]

59. Westoby, M.; Leishman, M.; Lord, J. Comparative ecology of seed size and dispersal. Philos. Trans. R. Soc. Lond. Ser. B Biol. Sci. 1996, 351, 1309-1318. [CrossRef]

60. Fenner, M. Environmental influences on seed size and composition. In Horticultural Reviews; John Wiley \& Sons, Ltd.: Hoboken, NJ, USA, 1992; pp. 183-213. ISBN 978-0-470-65050-9.

61. Matías, L.; Abdelaziz, M.; Godoy, O.; Gómez-Aparicio, L. Disentangling the climatic and biotic factors driving changes in the dynamics of Quercus suber populations across the species' latitudinal range. Divers. Distrib. 2019, 25, 524-535. [CrossRef]

62. Urbieta, I.; Pérez-Ramos, I.M.; Zavala, M.A.; Marañón, T.; Kobe, R.K. Soil water content and emergence time control seedling establishment in three co-occurring Mediterranean oak species. Can. J. For. Res. 2008. [CrossRef]

63. Solla, A.; Milanović, S.; Gallardo, A.; Bueno, A.; Corcobado, T.; Cáceres, Y.; Morcuende, D.; Quesada, A.; Moreno, G.; Pulido, F. Genetic determination of tannins and herbivore resistance in Quercus ilex. Tree Gen. Genom. 2016, 12, 117. [CrossRef]

64. Corcobado, T.; Miranda-Torres, J.J.; Martín-García, J.; Jung, T.; Solla, A. Early survival of Quercus ilex subspecies from different populations after infections and co-infections by multiple Phytophthora species. Plant Pathol. 2017, 66, 792-804. [CrossRef]

65. Ramírez-Valiente, V.A.; Valladares, F.; Gil, L.; Aranda, I. Population differences in juvenile survival under increasing drought are mediated by seed size in cork oak (Quercus suber L.). For. Ecol. Manag. 2009, 257, 1676-1683. [CrossRef]

66. González-Rodríguez, V.; Villar, R.; Navarro-Cerrillo, R.M. Maternal influences on seed mass effect and initial seedling growth in four Quercus species. Acta Oecol. 2011, 37, 1-9. [CrossRef]

67. Landergott, U.; Gugerli, F.; Hoebee, S.E.; Finkeldey, R.; Holderegger, R. Effects of seed mass on seedling height and competition in European white oaks. Flora 2012, 207, 721-725. [CrossRef]

68. Zas, R.; Cendán, C.; Sampedro, L. Mediation of seed provisioning in the transmission of environmental maternal effects in Maritime pine (Pinus pinaster Aiton). Heredity 2013, 111, 248-255. [CrossRef]

69. Vázquez, F.M. Semillas del Género Quercus L. (Biología, Ecología y Manejo); Junta de Extremadura, Consejería de Agricultura y Desarrollo Rural: Badajoz, Spain, 1998; ISBN 978-84-8107-028-6.

70. Serrano, M.S. Control Cultural de la Podredumbre Radical Causada por Phytophthora Cinnamomi en Dehesas de Encina; Universidad de Córdoba: Córdoba, Spain, 2012.

71. Ramírez Lozano, F.; Peinado Lucena, E.; Medina Blanco, M.; Rodríguez Berrocal, J.; Gómez-Castro, A.G. Valoración de frutos de Quercus ilex L. en función de la concentración de taninos. Arch. Zootec. 1983, 32, 1-3.

72. Alcaide, F.; Solla, A.; Cherubini, M.; Mattioni, C.; Cuenca, B.; Camisón, Á.; Martín, M.Á. Adaptive evolution of chestnut forests to the impact of ink disease in Spain. J. Syst. Evol. 2020, 58, 504-516. [CrossRef]

73. Redondo, M.Á.; Pérez-Sierra, A.; Abad-Campos, P.; Torres, L.; Solla, A.; Reig-Armiñana, J.; García-Breijo, F. Histology of Quercus ilex roots during infection by Phytophthora cinnamomi. Trees 2015, 29, 1943-1957. [CrossRef]

74. McConnell, M.E.; Balci, Y.; Woodward, S. Fine root dynamics of oak saplings in response to Phytophthora cinnamomi infection under different temperatures and durations. For. Pathol. 2015, 45, 155-164. [CrossRef]

75. Sampedro, L. Physiological trade-offs in the complexity of pine tree defensive chemistry. Tree Physiol. 2014, 34, 915-918. [CrossRef]

76. López-Goldar, X.; Zas, R.; Sampedro, L. Resource availability drives microevolutionary patterns of plant defences. Funct. Ecol. 2020, 34, 1640-1652. [CrossRef]

77. Morcillo, M.; Sales, E.; Ponce, L.; Guillén, A.; Segura, J.; Arrillaga, I. Effect of elicitors on holm oak somatic embryo development and efficacy inducing tolerance to Phytophthora cinnamomi. Sci. Rep. 2020, 10, 15166. [CrossRef] [PubMed]

78. Stassen, J.H.M.; López, A.; Jain, R.; Pascual-Pardo, D.; Luna, E.; Smith, L.; Ton, J. The relationship between transgenerational acquired resistance and global DNA methylation in Arabidopsis. Sci. Rep. 2018. [CrossRef] [PubMed]

79. Martínez, M.T.; San-José, M.d.C.; Arrillaga, I.; Cano, V.; Morcillo, M.; Cernadas, M.J.; Corredoira, E. Holm oak somatic embryogenesis: Current status and future perspectives. Front. Plant Sci. 2019, 10. [CrossRef] [PubMed]

80. Martínez, M.T.; Vieitez, F.J.; Solla, A.; Tapias, R.; Ramírez-Martín, N.; Corredoira, E. Vegetative propagation of Phytophthora cinnamomi-Tolerant holm oak genotypes by axillary budding and somatic embryogenesis. Forests 2020, 11, 841. [CrossRef] 